\title{
Using Road Maps for High-Tech Projects Management
}

\author{
VALERIY BUNAK, ELENA PROKHOROVA, VLADIMIR ZHURAVSKY, SERGEI VOLODIN, \\ ANDREI FROLOV \\ Institute of Engineering Economics and Humanitarian Studies MAI \\ Moscow Aviation Institute (National Research University) \\ 4 Volokolamskoe highway, Moscow, 125993, \\ RUSSIAN FEDERATION
}

\begin{abstract}
The purpose of this article is to study the necessity of creation and road maps usage as an effective tool in order to create novel approaches for managing innovative high-tech projects using the author-developed criterion of innovative tension, interpreted as the difference of potentials of participants in the innovation process - the donor-enterprise of innovations and the recipient-enterprise of innovations. The method of comparative analysis of various forms of organization of the innovation process and the corresponding variants of the ratio of innovative potentials of participating enterprises was used. As a result of the conducted research, methodical approaches to evaluate innovation potentials of donors-enterprises of innovations and enterprisesrecipients of innovations were developed. A criterion for estimating the innovative potential in the donorrecipient system, so-called innovative stress, is formulated. An attempt to disclose the importance of methodological support of road maps on the example of innovative projects is made.
\end{abstract}

Key-Words: Human, logistic, finance management, capacity indicators, innovative potentials, road maps, RCP

Received: April 19, 2021. Revised: January 13, 2022. Accepted: January 27, 2022. Published: February 12, 2022.

\section{Introduction}

In the current conditions of the country's economic development and its individual sectors, the factors "innovative challenges," "technological challenges" have a deep meaning and significance as the motivating reasons for the formation of strategic development goals. For simplifying proposed procedures among the new modern tools for planning and managing innovative projects, a technology of road map had been represented [1], [2], [3].

The road maps were essentially the most important management tools and, as a feature, are very diverse, heterogeneous, understandable, and solve important task-facilitating decision-making processes in the conditions of a technological challenge. However, at the same time, a "challenge" which is based on this technology is considered in good detection and understanding of threats (not necessarily fatal) with further requiring of mandatory responses [4]. In this regard, such periods of economic development of the country and its individual sectors are accompanied by the appearance of such tools as, for example, innovation studies [5], [6], [7], [8].

\section{Methodology}

The category of innovative potential is used as the fundamental basis of this research and is considered in two ways:

1) the innovative potential of the enterprise-donor of innovations;

2) the innovative potential of enterprise-recipient of innovations (of the consumer in various sectors of the national economy and social sphere).

In this case, the innovative potential can be defined as the range of resources and capacities that can be involved in the innovative development of individual enterprises and industry in general and for the development and output of innovative products in implementing knowledge-based projects programs.

To achieve the research goal, methods of economic forecasting and factor analysis of the innovative potential of enterprise-participants in the innovation process were used. When assessing the necessary investment of innovative processes, economic analysis, and economic efficiency evaluation methods were used. Techniques of innovative management are used in constructing a model of innovation processes for enterprisesdonors of innovations and enterprises-recipients of innovation. 


\section{Results}

Different tools may be used to assess the innovative capacity of enterprises and institutions. It is possible to apply the known concept of SWOT (Strengths are principal effects, Weaknesses are weak points, Opportunities are possibilities, and Threats are risks) analysis in a relatively stable economic environment. In analytic terms, the intersection of strengths (internal environment) and possibilities (external environment) needs to be considered in the innovative potential of an enterprise. The best results of SWOT analysis are achieved in a relatively stable external environment. Under its turbulent conditions, unused capabilities easily become threats, and strengths can become weaknesses. In this situation, the concept of resources and capabilities is updated to assess innovation potential (resource approach, according to the classical R. Grant concept of strategic management).

Availability of resources is necessary but not a sufficient condition for realizing innovative potential, particularly where there is effective competition, always present in regional and world markets, and, to a lesser extent, on the internal. The higher category using a resource approach is the ability to perform certain activities, which are based on available resources but are highly competitive which are not guaranteed by the possession of administrative, natural, or other types of resources.

Yet, a lack of resources essential to the activity limits the development of necessary abilities. An example is the inability to meet high qualifications and the personnel's professional competence to the lack of modern equipment. Therefore, to objectively assess an economic actor's innovation potential at any level (industries, organizations, etc.), it needs to be reviewed for the relevance of a competitive advantage strategy based on their ability and resources (Table 1).

Table 1. Interlinkages of resources, capacities, and innovative capacities

\begin{tabular}{|c|c|c|c|}
\hline & & High & Low \\
\hline $\begin{array}{c}\text { Abilitie } \\
\mathbf{S}\end{array}$ & High & $\begin{array}{c}\text { Acquisition of } \\
\text { resourses is } \\
\text { required }\end{array}$ & $\begin{array}{c}\text { High innovative } \\
\text { potential }\end{array}$ \\
\cline { 2 - 4 } & Low & $\begin{array}{c}\text { Lack of } \\
\text { innovative } \\
\text { potential }\end{array}$ & $\begin{array}{c}\text { Development of } \\
\text { innovative } \\
\text { abilities is needed }\end{array}$ \\
\hline
\end{tabular}

Table 2 lists the factors influencing innovation capacity developers and consumers of innovative products. Realization of all developer's activities to enhance resources and capabilities increases its value to consumers and producers' incomes.

Table 2. Factors affecting the innovation capacity of innovators and consumers of innovative production

\begin{tabular}{|c|c|c|}
\hline \multirow{2}{*}{ Factors } & \multicolumn{2}{|c|}{ Innovative potential } \\
\hline & Producers & Consumer \\
\hline $\begin{array}{l}\text { Resource } \\
\text { s and } \\
\text { assets }\end{array}$ & \multicolumn{2}{|c|}{$\begin{array}{c}\text { Human } \\
\text { Logistical } \\
\text { Financial } \\
\text { Intangible }\end{array}$} \\
\hline \multirow{4}{*}{ Abilities } & $\begin{array}{l}\text { Customers } \\
\text { relationship } \\
\text { management }\end{array}$ & $\begin{array}{c}\text { Producers } \\
\text { relationship } \\
\text { management }\end{array}$ \\
\hline & $\begin{array}{l}\text { Generating the } \\
\text { innovations } \\
\text { Project time, cost, } \\
\text { and quality } \\
\text { management } \\
\text { Human resource } \\
\text { management } \\
\text { Science and } \\
\text { technology risk } \\
\text { management } \\
\text { Supplier of } \\
\text { components } \\
\text { management }\end{array}$ & $\begin{array}{l}\text { Skilled operating } \\
\text { Management of } \\
\text { cost and quality } \\
\text { of operation } \\
\text { HR Management, } \\
\text { Operational risk } \\
\text { management }\end{array}$ \\
\hline & $\begin{array}{l}\text { Technology } \\
\text { transfer in the } \\
\text { development } \\
\text { phase }\end{array}$ & $\begin{array}{c}\text { Mastering } \\
\text { innovative } \\
\text { products in the } \\
\text { operational phase }\end{array}$ \\
\hline & \multicolumn{2}{|c|}{$\begin{array}{l}\text { Bearing in mind the positions of } \\
\text { project stakeholders } \\
\text { Personnel qualification } \\
\text { Ability to manage assets } \\
\text { Ability to attract and retain resources } \\
\text { Ability to transform resources and } \\
\text { assets into new competencies }\end{array}$} \\
\hline
\end{tabular}

The state of innovation capacity can also be defined using different reference group indexes. For this work can be identified such groups as targeted (affecting the efficiency and effectiveness of innovative projects), temporary (affecting the timing and milestones of the implementation of innovative projects), cost (affecting the feasibility base, investment analysis, and the process of budgeting innovative projects). Results of a possible preliminary option grouping innovation capacity of industry (enterprises) the disclosure of their meaning are shown in Table 3.

Table 3. Innovation capacity indicators

\begin{tabular}{|c|c|c|}
\hline $\begin{array}{c}\text { Innovativ } \\
\text { e potential } \\
\text { indexes }\end{array}$ & Resources & Abilities \\
\hline Targeted & Infrastructure assets & Staff skills and \\
\hline
\end{tabular}




\begin{tabular}{|c|c|c|}
\hline & $\begin{array}{c}\text { availability } \\
\text { (human, material, } \\
\text { and financial } \\
\text { assets) } \\
\text { The proportion of } \\
\text { intangible assets } \\
\text { Depreciation of } \\
\text { assets involved in } \\
\text { the innovation } \\
\text { process } \\
\text { The proportion of } \\
\text { innovative products } \\
\text { innovation in the } \\
\text { overall portfolio of } \\
\text { programs and } \\
\text { projects } \\
\text { Access to scarce } \\
\text { resources }\end{array}$ & $\begin{array}{l}\text { intellectual capital } \\
\text { Working efficiency } \\
\text { The proportion in } \\
\text { prospective market } \\
\text { segments } \\
\text { Membership of } \\
\text { leading industry } \\
\text { groups of } \\
\text { competitors } \\
\text { Development } \\
\text { innovation } \\
\text { (reliability of } \\
\text { products and } \\
\text { processes to certain } \\
\text { stages of their life } \\
\text { cycle) }\end{array}$ \\
\hline $\begin{array}{c}\text { Temporar } \\
\mathbf{y}\end{array}$ & $\begin{array}{l}\text { Age of property, } \\
\text { plant, and } \\
\text { equipment } \\
\text { Market growth } \\
\text { The time available } \\
\text { for REDW } \\
\text { (Research, } \\
\text { experimental, and } \\
\text { design works) } \\
\text { based on a market } \\
\text { readiness to accept } \\
\text { innovation }\end{array}$ & $\begin{array}{l}\text { Time for carrying } \\
\text { out the REDW } \\
\text { (Research, } \\
\text { experimental, and } \\
\text { design works) for } \\
\text { (technological } \\
\text { training and } \\
\text { production cycle) } \\
\text { Maintenance time } \\
\text { of previous designs }\end{array}$ \\
\hline Cost & Cost of updating & Costs of REDW \\
\hline
\end{tabular}

\begin{tabular}{|l|c|c|}
\hline & $\begin{array}{c}\text { property, plant, and } \\
\text { equipment } \\
\text { Cost of license } \\
\text { obtaining }\end{array}$ & $\begin{array}{c}\text { (Research, } \\
\text { experimental, and } \\
\text { design works) } \\
\text { Impact on market } \\
\text { prices }\end{array}$ \\
& $\begin{array}{c}\text { Implementation of } \\
\text { strategies } \\
\end{array}$ \\
& Turnover in \\
& innovative market \\
& segments \\
\hline
\end{tabular}

Traditional project and program investment performance indicators also characterize innovation potential. These include, first of all, the net present value of the innovation project, discounted payback period and internal rate of return, as well as the level of break-even sales.

Figure 1 represents the organizational structural model for creating an innovation potential of a donor-innovating enterprise [9], and Figure 2 - the innovation potential of a recipient enterprise of innovation [10], [11].

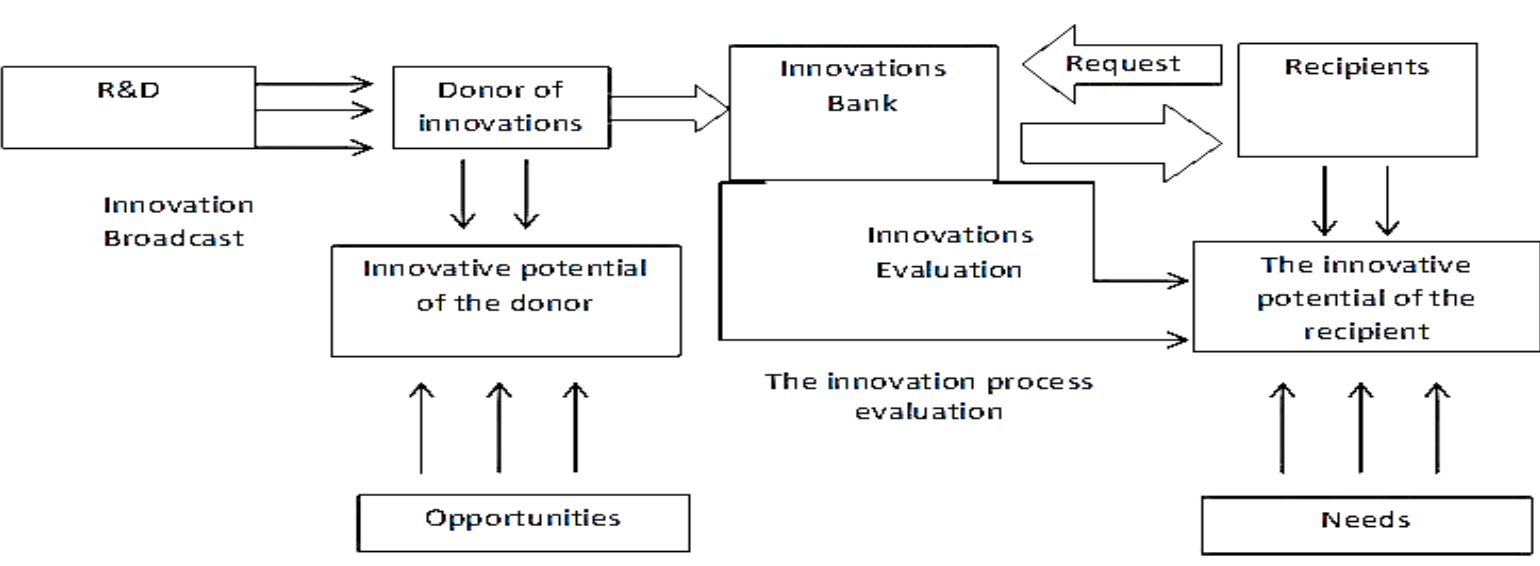

Fig. 1: Model of the innovation process from the donor-innovator (road map of the A) process. Source: authors

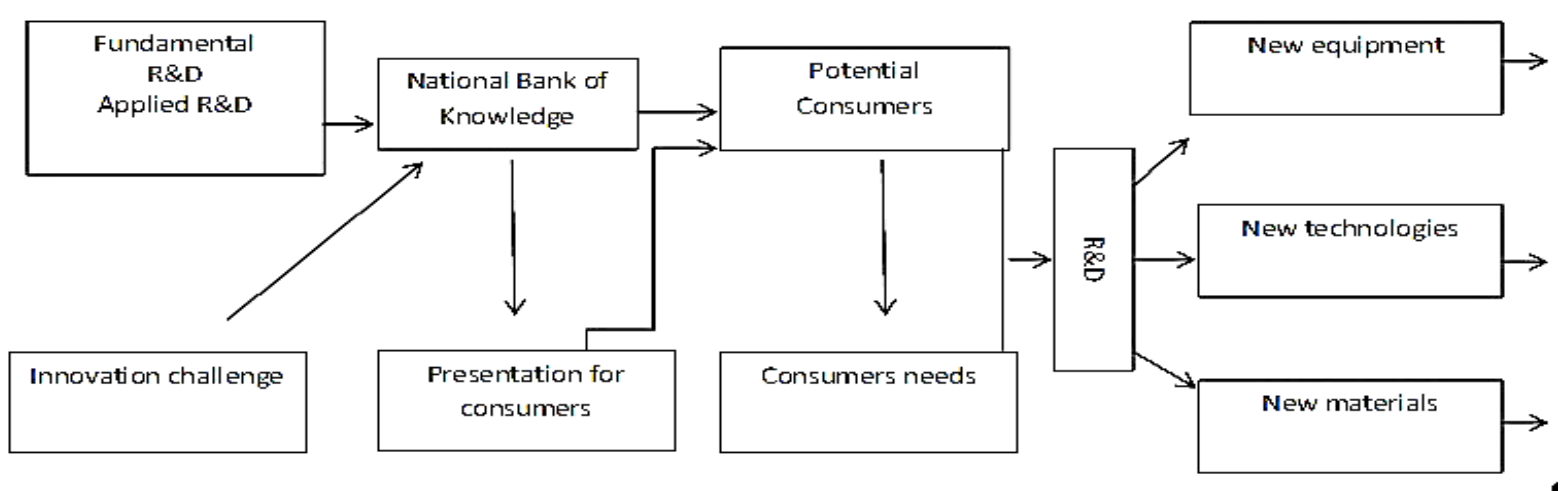

Fig. 2: Scheme of creation of innovative potential of enterprise-recipient of innovations (road map B). Source: authors 
The experience of innovation, shown schematically in Fig. 1 shows that donor enterprises carry out their activities mainly in industries that are in the stage of emergence or growth. At the same time, recipient enterprises operate, as a rule, in mature industries, although some exceptions to this pattern are possible.

The diagram presented in Fig. 2 makes it possible to assess one of the central problems of innovation activity and determines the ways of its solution. If there is no innovation, then starting an innovative activity means going on a guaranteed failure, since for success it is necessary to have a real innovation that has passed the stage of $R \& D$.

In recent years, the innovative activity of the Russian Federation has acquired the scope of obligations, guaranteed success, and guaranteed financing in a wide range of human activities, including education, upbringing, sports and culture, medicine, recreation, feeding, etc., as well as production (industry and agriculture) and so on [12]. At the same time, excessive enthusiasm for innovation studies in some cases contradicts the laws of dialectics and healthy effective conservatism. In other words, we do not live in the field of a healthy combination of innovation and conservatism, but in the field of innovative fashion. What is more, it causes legislative and even safety problems due to the Russian Federation's legislation being unable to effectively incorporate and regulate changes, especially in a technological sphere [13].

At the same time, we have fantastic results of effective, innovative activity in a number of branches of the scientific and socio-economic complex of the Russian Federation. In them, innovation is not a fashion, but a normal mode of operation, where it is not customary to use the medical term "innovation" but receive world-class results [14], [15]. The high integrity of regional innovation systems results in numerous positive externalities: from new firm creation, especially in the high-tech sector, and growing variety of industry sector to the involvement in global value chains, the influx of qualified workforce and infrastructure development [16], clusters' network development [17]. The rocket and space industry (RCP) undoubtedly belong to such spheres, industries, and enterprises, which objectively is a donor of innovations that are broadcast to many spheres of life, without which mankind no longer thinks of its existence, for example, navigation services of the Russian space system GLONASS [18], [19].

\subsection{Methodological Approaches to Assess the Effectiveness of Innovation Activities of Enterprises of the RCP}

Methodical approaches to the selection of the criteria base and calculation algorithms can be different, but a must for them is sensitivity to effects of a different nature (scientific-technical, innovation, social, environmental, economic, and others).

1. The first approach is that, as an active donor of innovations, the RCP needs to evaluate its innovative activity and evaluate the effectiveness of projects from the standpoint of a system of criteria that takes into account the role, influence, and features of projects in the economic, political, social and other spheres of life. Meantime, when the space market has developed - segmented, competitive, highly profitable, innovative, politicized, capitalintensive, etc., the relevance of the problems of methodological support of assessments of the space activities effectiveness is undeniable [20].

2. The second approach is that, as the donor of innovations is simultaneously a recipient. Donors for it can be academic and research institutes, foreign science-intensive firms, a licensed market, the experience of international cooperation, interstate innovation projects and programs, etc. Recently, the Chinese experience of innovative development is serving as a serious donor. It is important to note that the rocket and space industry (RSI) is the most serious donor in the Russian Federation for other sectors of the scientific and socio-economic complex. High-tech and high-tech innovations are most in-demand in this industry [21]. Many of them have found practical application in solving problems in such areas of space activities as space communications, telecommunications, space systems for remote sensing of the earth and the ocean in the interests of various branches of the scientific and socioeconomic complex of Russia, navigation space systems, manned space exploration, space medicine, etc. These directions of DC give innovative concrete results and bring them to the household consumption format.

When creating technological road maps for DC's development, an important issue is to ensure a minimum gap in the innovative potentials of the donor and the recipient. The innovation donor's potential, which forms the portfolio of opportunities, is largely ensured by the organization and amount of funding for projects and programs. These opportunities can exceed the need for innovation among consumers of innovations. 
For a successful organization of an innovative process, the ratio (difference) of the initial and final level of potentials should tend to zero or a minimum. The innovation process, which is carried out with equal potentials, is ideally organized.
Figure 3 shows the possible three options for the ratio of potentials of the donor and the consumer (recipient).

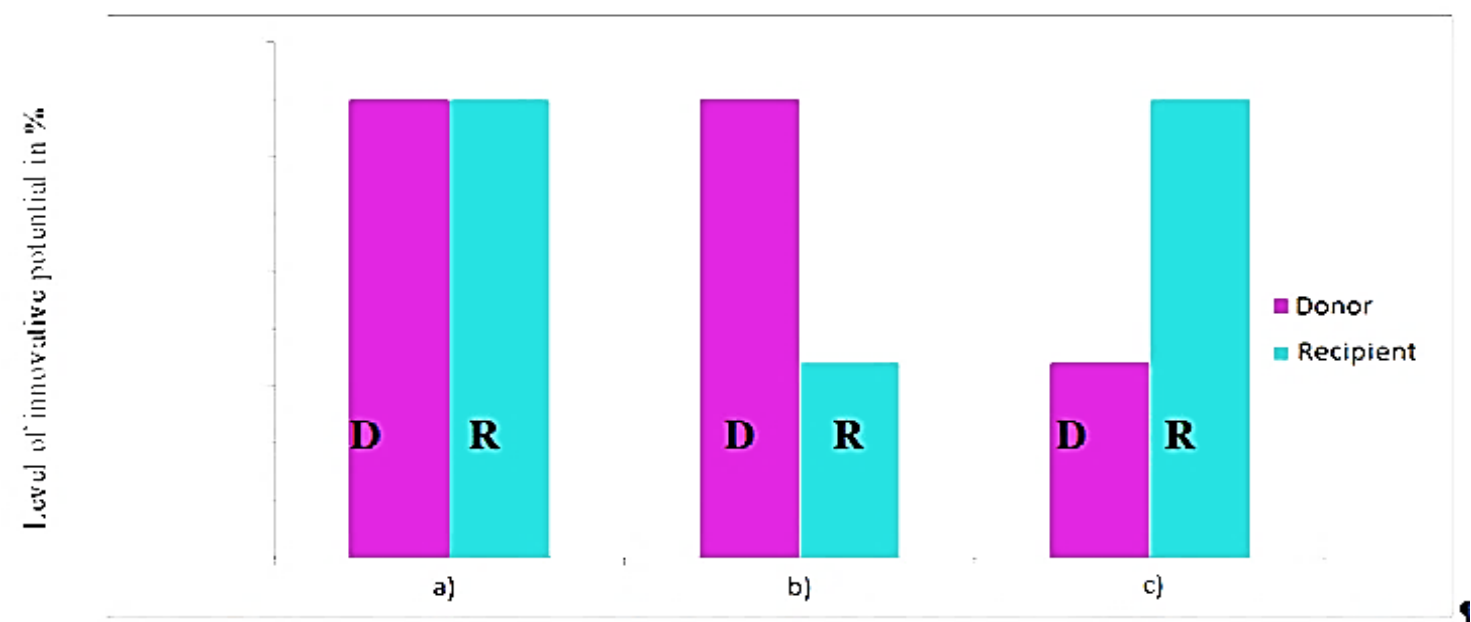

Fig. 3: Options of the ratios of the innovative potentials of the donor and recipient Source: authors

\section{Discussion}

In Russia, ensuring the ideal combination of innovative donor and recipient potentials is seriously hampered by the following circumstances:

a. Low level of the cost ratio for the intellectual component and for materials and energy. This is due to low labor productivity in the Russian Federation in comparison with the developed countries [22]. The indicator "GDP" per working person in Russia is 5-6 times lower than in the leading developed countries.

b. Another factor that makes it difficult to ensure an acceptable ratio of requests from recipients and the ability of donors to innovate in the Russian Federation is the low level of funding for research and development (R\&D) and increased expenses on foreign technologies, equipment, licenses, etc [16].

c. In Russia, $R \& D$ expenditures are about $1 \%$ of GDP, and in developed countries (the United States, Japan, Germany, China), 8-10\% of GDP. As for RCI, we are comforted here only by the sprouts of reduction of this gap and the prospects for the commercialization of space activities.

d. On the other hand, the slow participation of commercial structures in investments in the R\&D of rocket and space technology is disturbing. The state pursues a policy of amnesty (forgiveness) of huge investments in the creation of rocket and space technology, ground infrastructure, etc. The net income from the implementation of such a policy for commercial structures provides significant profitability for the operator firms, but, as a rule, this revenue goes from the budget of the industry, the country.

Figure 3 represents that when the potential of the donor and the recipient is equal (option a), we have the ideal combination, which means that there is no need for investment in either direction of the innovation process. Option b) shows that the consumer is ready to "swallow" more innovations, and the donor is not able to satisfy such a request due to underfunding of R\&D. Option c) corresponds to the situation when the vessel of knowledge is full, and consumers are not able to "swallow" these innovations. The backwardness of consumers from the possibilities of modernization is explained by the insufficient innovative potential of recipients. Another reason is the backwardness, neglect of the consumption infrastructure. In the old years, we saw this picture in the form of a pile of unidentified imported equipment, which for years waited in vain for use. Thus, the high potential difference between the donor and the recipient is a negative state, which must be minimized.

The Department of Economics of the Aerospace Industry of the MAI as a result of research into the innovative sphere of the RCP developed methodological approaches to assess the innovative potential of the donor-recipient system [23] and formulated a criterion for such an assessment in the form of a difference in the innovative potentials of 
the donor and recipient, as a potential difference by analogy with electrical engineering - W. In general, the criterion $\mathrm{W}$ is calculated by the formula (1):

$$
W=\left|P_{D}-P_{K}\right| \rightarrow \min ,
$$

where PD - the innovative potential of the enterprise - the donor of innovations; PK - the innovative potential of the enterprise - the recipient of innovations.

The criterion of innovative voltage Wallows to solve the following tasks:

a. to choose an effective, innovative project rationally;

b. to determine the volume of financial injections either into R zone or D zone, which corresponds to options b) and c) of Figure 3;

c. to optimize innovative projects;

d. to assess the competitiveness of innovative projects;

e. to ensure the monitoring of the donor-recipient potential;

f. to use the criterion of innovative tension to conduct the correct financial and credit policies of project participants;

g. to calculate the current value of the boundaries of the security corridor of innovative projects, etc.

The security corridor shows the possibilities of managing the financing of innovative projects and the possibility of adjusting the thresholds for financing, which, as is well known, are tightly tied to the financial field. A particularly important result of project management in this context is the boundaries of the security corridor and its sustainability. All this can be achieved by reducing the innovative tension in the projects. The above variants of the ratio of the innovative potentials of the donor and the recipient create the basis for the management of high-tech projects using road maps.

\section{Conclusion}

Inherently, in this article, an attempt to disclose the importance of methodological support of road maps on the example of innovative projects is made. It is significant to assume that variants of the ratio of enterprises' innovation potentials form the basis for effective management of innovative high-tech projects using road maps.

The need for more active participation of commercial structures in investments in R\&D of rocket and space technology was identified
The authors formulated the criterion of innovative stress and proposed a variant of calculating the safety corridor for innovative projects.

Considering the method of comparative analysis of various forms of organization of the innovation process and the corresponding variants of the ratio of innovative potentials of participating enterprises was used. As a result of the conducted research, methodical approaches had evaluated an innovation potential of donors-enterprises of innovations and enterprises-recipients of innovations were developed. At the same time, the principles outlined in the article are considered in the context of the possibilities of road maps as the most appropriate tools for solving many problems of innovative technological development in the face of modern challenges.

To provide a basic theoretical basis for innovation, it is necessary to continue developing a system of indicators, criteria for choosing the most effective innovation option.

References:

[1] Comp. Mech. Lab, Road map approved by the Presidium of the Council under the President of 2017, Protocol No. 1, 2017. http://fea.ru/compound/national-technologyinitiative

[2] Baikov, E.A., Introduction of innovative technologies of road mapping into the practice of strategic enterprise management. Economic portal.

$\mathrm{http}$ //institutiones.com/innovations/2432vnedrenie-innovacionnyx-texnologiydorozhnogo-kartirovaniya.html

[3] Korunov, S.S., Methodical principles of economic justification for routing innovation processes in the aerospace industry. Proceedings of the XXXVII academic readings on cosmonautics. Moscow: Commission of the Russian Academy of Sciences Press, 2013.

[4] Baikov, E.A., Strategic management of enterprises in conditions of instability: monograph, Saarbrucken: LAMBERT Academic Publishing Centre, 2014.

[5] Vasilenko, N.V., Managing the development of innovation in universities: monograph, StPeterburg: Publishing House of the Russian State Pedagogical University, 2013.

[6] Vlasov, A.I, Grigoriev P.V., Krivoshein, A.I. Shakhnov, V.A. Filin, S.S., \& Migalin, V.S., Smart management of technologies: predictive maintenance of industrial equipment using wireless sensor networks. Entrepreneurship and Sustainability Issues, Vol. 6, No. 2, 2019, 
pp.

489-502.

http://doi.org/10.9770/jesi.2018.6.2(2).

[7] Batkovski, A.M., Efimova, N.S., Kalachanov, V.D., Semenova, E.G., Fomina, A.V., \& Balashov, V.M., Evaluation of the efficiency of industrial management in high-technology industries. Entrepreneurship and Sustainability Issues, Vol. 6, No. 2, 2018, pp. 577-590. http://doi.org/10.9770/jesi.2018.6.2(8).

[8] Illmeyer, M., Grosch, D., Kittler, M., \& Pamela Priess. P., The impact of financial management on innovation. Entrepreneurship and Sustainability Issues, Vol. 5, No. 1, 2017, pp. 58-71. http://doi.org/10.9770/jesi.2017.5.1(5)

[9] Gorbunov, S.S., Organizational and economic approaches and tools for the development of innovative processes in the rocket and space industry: textbook, Moscow: Dobroslovo Press, 2015.

[10] Magomaeva, L.R., Analysis methods for providing a balance between risk investors and risk to the recipient of investments. Modern problems of science and education, Vol. 4, 2012. https://scienceeducation.ru/en/article/view?id=6652.

[11] Ignatenko, Yu.V., Stratification of target groups of innovation recipients in an innovative cluster. Economics and Banks, Vol. 2, 2016, pp. 80-86.

[12] Tsyplova, S.A., Sources of financing of innovative activity of enterprises in Russia. https://novainfo.ru/article/?nid=4214.

[13] Rybkina A.M., \& Demidova P.M., Features of cadastral work in relation to road transport constructions. IOP Conference Series: Earth and Environmental Science, 2019. http://doi.org/10.1088/17551315/403/1/012214

[14] Romanov, A.A., Development of a science and technology basis for the creation of advanced space engineering technologies. Rocket-Space Device Engineering and Information Systems, Vol. 3, No. 4, 2016, pp. 48-64.

[15] Pogodina, T.V., Aleksakhina, V.G., Burenin, V.A., Polianova, T.N., \& Yunusov, L.A., Towards the innovation-focused industry development in a climate of digitalization: the case of Russia. Entrepreneurship and Sustainability Issues, Vol. 6, No. 4, 2019, pp. 1897-1906. http://doi.org/10.9770/jesi.2019.6.4(25)

[16] Mikhaylov, A.S., Mikhaylova, A.A., \& Savchina, O.V., Innovation security of crossborder innovative milieu. Entrepreneurship and Sustainability Issues, Vol. 6, No. 2, 2018, pp. 754-766. DOI:10.9770/jesi.2018.6.2(19)

[17] Abramov, R.A., Regional economic policy based on industrial sector clustering in the context of sustainable development. Research Journal of Pharmaceutical, Biological and Chemical Sciences, Vol. 7, No. 2, 2016, pp. 2100-2106.

[18] Volodin, S.V., \& Korunov, S.S., Aerospace programs management: engineering and economical approach, Moscow: Dobroslovo Press, 2014.

[19] Federal target programs of Russia, Program "Maintenance, development and use of the GLONASS system for 2012-2020", 2015. http://fcp.economy.gov.ru/cgibin/cis/fcp.cgi/Fcp/ViewFcp/View/2015/396.

[20] Okatieva, N.V., Russia's position on the world market of space products and services. Business and law, Vol. 6, 2012, pp. 324-330.

[21] Kuibyshev, A., Management of innovative projects. The information support portal for innovation and business. http://www.innovbusiness.ru/content/document r_0AFD1368-94B2-423E-BA0A$\overline{\mathrm{D}} \overline{\mathrm{EF}}$ 99A6C416F.html

[22] Frolova, I.I., Nosov, V.V., Zavyalova, N.B., Dorofeev, A.E., Vorozheykina, T.M., \& Petrova, L.I., Labor opportunism as a blocking factor for the innovative development of industrial enterprises. Entrepreneurship and Sustainability Issues, Vol. 7, No. 3, 2020, pp. 2228-2242.

http://doi.org/10.9770/jesi.2020.7.3(51)

[23] Gorbunov, S.S., Methods and models for assessing the economic efficiency of investment projects in the rocket and space industry, Moscow: Dobroslovo Press, 2015.

\section{Contribution of Individual Authors to the Creation of a Scientific Article (Ghostwriting Policy)}

Valeriy Bunak, Elena Prokhorova, Vladimir Zhuravsky, Sergei Volodin and Andrei Frolov were responsible for the conceptualization, supervision, and writing the article.

\section{Creative Commons Attribution License 4.0 (Attribution 4.0 International, CC BY 4.0)}

This article is published under the terms of the Creative Commons Attribution License 4.0 https://creativecommons.org/licenses/by/4.0/deed.en US 